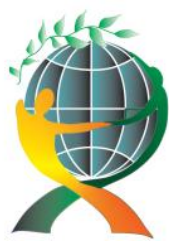

\author{
(online) $=$ ISSN $2285-3642$ \\ ISSN-L = $2285-3642$ \\ Journal of Economic Development, Environment and People \\ Volume 3, Issue 3, 2014 \\ URL: http://jedep.spiruharet.ro \\ e-mail: office jedep@spiruharet.ro
}

\title{
An Opinion on Strategic Directions for an Economy in the Capitalist Periphery: The Case of India
}

\author{
Sorab Sadri ${ }^{1}$ \\ ${ }^{1}$ Professor of Political Economy and Management Sciences and Dean of the Faculty of Management and \\ Commerce at JRCRC University, (JU) Jaipur, Rajasthan, sorab.sadri2010@gmail.com
}

\begin{abstract}
This paper is based on sixteen years of intensive examination and research into three Industrial Sectors (manufacturing, process and technology) of Western India and all observations contained herein are born out of and relate directly to those sectors. The premise upon which we stand is that if business ethics and corporate governance co-exists then with proper HR interventions a value centred corporate culture will very likely emerges and the journey towards achieving organisational excellence becomes that much easier. In the postgraduate textbook entitled Organisational Excellence through Business Ethics and Corporate Governance the authors had begun by defining ethics and stating that ethics was the precondition for generating value centred corporate cultures? They then delved deep into what ethics entrails and how it impacts the organisation as well as the individual within it. Thereafter they went in to the concept of Corporate Governance, defined it, viewed how it developed, examined how it was practiced overseas and then how it came to India. In this paper the authors attempt to show how good governance is based on ethics and how those who head the functions of People Management, Company Secretary, and Accountancy (cost and chartered) can gainfully use it for realising the larger interest of the organisations they belong to. To that extent, this paper is just what the title suggests: an opinion on the subject based on ongoing research.
\end{abstract}

Keywords: Industrial Sectors of Western India, business ethics, corporate governance, organisational excellence

JEL Codes: L22, J24, J53, O15

\section{Introduction}

Scholars agree that values are a thought based concept while ethics are an activity-based concept. There is a symbiotic relation between the two. Business Ethics gives us a macro picture of how corporate entities must behave within a given socio-political-economic-cultural environment. This ensures that neither the internal customer (employee) nor the external customer (client) is short-changed. (21) Managerial Ethics explains how executives react when faced with an ethical dilemma. To that extent, it is a micro manifestation of values.(44). 


\author{
(online) = ISSN $2285-3642$ \\ ISSN-L = 2285-3642 \\ Journal of Economic Development, Environment and People \\ Volume 3, Issue 3, 2014 \\ URL: $\underline{\text { http://jedep.spiruharet.ro }}$ \\ e-mail: office jedep@spiruharet.ro
}

\title{
2. Research Methodology
}

From ethics flows governance and research suggests that good corporate governance practices assist substantially in the journey towards achieving Organisational Excellence (45). The ongoing research studies on governance by Jairus Banaji in Oxford, Sunita Sharma in Baroda, Sanjeev Agarwal in Jaipur and Sharukh Tara in Mumbai distinctly point towards some credibility to this line of thought. (20) The work of J K Oke in Pune is audacious but being in its very nascent stage as such no specific comment on it can justifiably be made. Work done by individual members from the Institute of Company Secretaries and Bindi Mehta of NMIMS Mumbai is restricted to a treatment of regulators and regulations and it appears they are unable to conceptually transcend that limited paradigm. (43)

This conversion of good corporate governance practices into organisational excellence though highly desirable is by no means either automatic or as straight forward as it is made out to be. There are certain pre-conditions, as our studies from 1999 to date have indicated, for this successful conversion to take place. In keeping with this general belief, in Geometry of HR (2002) Sadri, Jayashree and Ajgaonkar (44) had attempted to focus on learning and innovation. The things firms need to do to be successful become the cause and the effect of this innovation. We had looked at innovation and learning as the solution to various problems that organization face and their justification within the framework of a Strategic HR Intervention. Once we had established to the veracity of this claim i.e. innovation and learning as the panacea for a majority of organizational ills, we concentrated on the actions and policies firms have to undertake to implement these credos. We thereafter attempted to debunk the idea of firms resorting to innovation and change as incremental, one-off measures can achieve excellence. The emphasis on learning and innovation cannot and should not be looked upon as short-term solutions, but as a way and means by which organization are run. (52) The culture of creativity and innovation cannot be inculcated in a short time; these are preceded by a painful transition phase, where long serving policies and philosophy have to be set aside in the interest of developmental growth without of course giving up the basic organisational values.(21)

For the above position to be actualised meaningfully, empty words and knee jerk reactions are hardly enough. The top managements had to be consistent, competent, credible and committed, on the one hand and possess the right values and should be prepared to stand by them, on the other. (1) This was unfortunately not always the case.

As the WTO regime unfolds in 2005 there has to be a major change, a paradigm shift, in the way management looks at the organization and the culture it wants to embed in the system. An end of ideology, on the lines of what Daniel Bell had written about, is very noticeable.(9) In fact, a radically different way of looking at the organisation has to evolve, wherein the focus of all management energies is the complete system. A holistic view of the organization, we argue, has to be developed, in which all ingredients synergize to form the complete whole, and concentrate on the achievement of the organizational goal. (20) We have to move away from the feudal-mercantilist-trader mindset and consciously imbibe the creativeinnovative-entrepreneurial mindset keeping ethics and governance as the two guideposts. (42)

Apart from leadership and top management, our study examined the role of the various management cadres and how they must adjust to the new philosophy. A culture, we believe, has to be inculcated in which values, creativity, individualism and reward systems, are merit based, and work climates in which a 


\author{
(online) $=$ ISSN $2285-3642$ \\ ISSN-L = 2285 - 3642 \\ Journal of Economic Development, Environment and People \\ Volume 3, Issue 3, 2014 \\ URL: http://jedep.spiruharet.ro \\ e-mail: office jedep@spiruharet.ro
}

person learns from failures, without being penalized are recognized and adopted.(10) Our study identified and isolated all the relevant factors that affect the evolution of such an organization. In reality, most of them were overlapping, and difficult to extricate but it had been our endeavour to attempt such a task. We concluded that an innovative and learning organization has the best chance to manage the violently dynamic environment and prove successful in the future. This sort of organization is best suited to react to upheavals in the market place, changing consumer preferences and the information and technological revolution is one that has a value centred corporate culture. Change in the 2003-13 has been conditioned by greater transparency and accountability thereby taking the wind out of the sails of the lumpen mediocrity.(43)

As Sadri and Ajgaonkar (2003) had argued an innovative organization will be best suited to retain the best talent within the organization. (42) The advent of the knowledge worker - sans geographical boundaries, has made it imperative for organization to foster an environment of learning, merit based reward systems and a culture that constantly seeks to better the past. This is the only way one can remain competitive and decision-making can be fair and objective even when the levels of uncertainty are relatively high.(43)

We also discovered that many organizations including some in the academic world had regressed from being entrepreneurial to being mercantilist. Perhaps this was due to knee jerk reactions in the face of unexpected turbulence in the market or in the work environment. Perhaps this was because those who controlled these organizations suffered from what Van Dusen Kennedy (1965) once referred to as tendermindedness, and which can be defined as high mindedness not sufficiently conditioned by intellect.(23) The question is then raised as to why should even such organizations today be concerned with fostering creativity and innovation. The obvious reason is that creativity and innovation are clichés used as window dressing to facelift the image of the organisation. Clearly those that look at short run actual costs and neglect long run opportunity costs will soon be consigned to the trash can of history irrespective of how fanciful the window dressing is. (3) We can safely discount these organisations from our discourse.

Instead, let us concentrate on those that are aiming of excellence in order to thrive on the cutting edge of market competition. Business research (5) on successful and failed companies, we further discovered, identifies five key reasons viz.

- Superior long-term financial performance is associated with innovation. The companies that is most successful at building shareholder wealth over the long-term stress innovation as a corporate value. (4)

- Customers are increasingly demanding innovation. Because customers experience new ideas and technologies daily, they have come to expect innovation in all the goods and services they use. Adler (2) followed by Deming cites the need for innovation in saying that it is not sufficient anymore to simply have happy, loyal customers.

- Competitors are becoming better at copying past innovations. (8) Last five year's innovations are quickly reverse-engineered and replicated. Patents offer little guarantee of exclusivity especially in the face of an archaic judicial system like that in India. Continuous innovation is needed to stay ahead in the marketplace.

- New technologies enable innovation. Joseph L. Bower and Clayton M. Christensen's research on business success and failure in technology-intensive industries illustrates a simple principle (44): If a 


\author{
(online) = ISSN $2285-3642$ \\ ISSN-L = 2285-3642 \\ Journal of Economic Development, Environment and People \\ Volume 3, Issue 3, 2014 \\ URL: http://jedep.spiruharet.ro \\ e-mail: office jedep@spiruharet.ro
}

company doesn't exploit innovative technology its competitors will, and they will take the market with them.

- What used to work doesn't anymore. Increasing complexity and interconnectedness requires taking a fresh look at old problems. And this needs persons who are experts and have the courage and the gumption to do so. (4) In the legal field we in India have the likes of Fali Nariman, in industry we have the likes of Narayana Murthy, and in academia we have Narayan Sheth who speak their mind plainly but always with decorum. (20)

What India needs is a total change in its thought and action processes, which produce a technology enabled and creativity driven revolution so as to become and remain globally competitive. A vital attribute of the technological revolution is the increasing importance of innovation and the diffusion of this innovation into the marketplace a la Peters and Waterman.(35) We are in the age of mass customisation, where according to Stein and Pinchot (53) we can even have highly complex products manufactured to our personal specifications in a short period. Speed now is of critical importance, while dramatic, radical innovations will frequently occur and become difficult to predict.(29) Because of frequent radical innovations, there is an increasing emphasis placed on designing new products and moving them into the marketplace rapidly. Customer Relationship Marketing (CRM) and Direct Marketing (DM) have logically gained dominance therefore. The development cycle of new products is shortened and obsolescence sets in rather quickly since new products and processes enter the market with great rapidity. (30). For example, in the late 1980s and early 1990s, U.S. manufacturers required 5 to 8 years to develop and move a new automobile design to the marketplace, whereas Japanese manufacturers undertook similar actions in approximately 3 years. Today, U.S. manufacturers have shortened their development cycles to between 36 and 45 months. However, the record set by Toyota according to Abraham was still pegged at 15 months in 2002. This forces the industry to develop best practices so that an organisation can stay abreast with the competition.

It is imperative that in the days to come best practices in every field have to be ascertained and benchmarked against and Strategic HR needs to take the lead in enabling this. In India, experts like Nawshir Mirza formerly of Ernst and Young and Tirpal Raju of SEBI have done some excellent work in developing best practices in the financial field. Sethu of the UTI Institute of Capital Markets has gone deep into audit committee work while Tara has developed a methodology for evaluating Corporate Governance in the financial Sector. Infosys has introduced labour costing (value addition per capita) in its annual report. Tata Steel has introduced several best practices in the production processes thereby giving it the organisation a globally competitive edge. The AICTE-NBA exercise of accreditation could also be seen as a move to benchmark best practices in the field of management education in the years to come. The only thing one must safeguard against in the AICTE-NBA type of exercise is that the purpose of inspection must not be eclipsed by the process of inspection. (45)

\title{
2.1. Best Practices for successful product innovation projects
}

Research has further indicated that Best Practices for successful product innovation projects are now pretty well established, and include the following: (45)

1. Market-technology linking: A product or service is a package that includes everything from the advertising message to the technology buried deeply within it. (52) Product innovation therefore comprises 


\author{
(online) = ISSN $2285-3642$ \\ ISSN-L = 2285-3642 \\ Journal of Economic Development, Environment and People \\ Volume 3, Issue 3, 2014 \\ URL: $\underline{\text { http://jedep.spiruharet.ro }}$ \\ e-mail: office jedep@spiruharet.ro
}

the conceptualisation, development, manufacture, launch, and ongoing management of this total package. (53) To create this package, the needs of customers must be both thoroughly assessed and linked with technology, and the major cause for new product failure is either the misunderstanding of or the complete exclusion of customer needs.(28)

2. Multi-functional Problem Solving: People from all departments must be involved in all aspects of the innovation process from working with customers to considering manufacturing options. (27) Product innovation is inherently multi-functional because no single functional expert knows all there is to know about the total package of features and benefits for any new product. Effective innovation also requires lateral working relationships that are extensive and trusting so that innovators can solve complex problems creatively and quickly. (28) However this will degenerate into a Mad Hatter's Tea Party without value centred culture and visionary leadership.

3. Evaluation: New product development projects must be evaluated over a period of time, often extending beyond the formal development phase itself. This evaluation should be objectively done keeping in mind the factors in the immediate environment that impinge upon persons and processes. (25) It must be done by experts whose technical competence and credibility are unquestioned or else it may degenerate into a witch-hunt where the lumped mediocrity calls the shots. (42)

4. Commitment: People must feel committed to innovation since it requires enormous investment in time, psychic energy, and attention. (50) It must fulfil the self-actualisation need to borrow the term from Abraham Maslow. If employees are to be committed, then first of all top management must demonstrate its commitment through positive action.

However, despite all the research and the effort to define practices to enable innovation, at best many organizations have had only experienced occasional successful product innovation. (54) Most companies unfortunately still cannot generate viable new products on a sustained basis in the Indian manufacturing sector. This, we reaffirm, has a lot to do with three factors: the abject paucity of value centred leadership at the top, the lumpen mediocrity that continues to call the shots and influence corporate policy, and the inability of People Management experts to rise to the occasion. The emasculation of the HR profession over the years has contributed to the absence of a countervailing tendency, as Sadri and Jayashree (1998) had lamented, leaving the top management to become totalitarian under the guise of pursuing long term interests fairness and growth. (42)

One obvious reason besides the three factors mentioned above is that product innovation is not simply a matter of managing single projects well. The organisation needs wide ranging policies and support structures (infra and super) (38) to make emulating each of the best practices listed above possible. More importantly and perhaps less obvious is that the very assumptions that traditional organizations have been modelled on has to be changed in order to ensure that the organizations are able to develop a culture of innovation. Missing the wood or the trees and failing to see the larger picture is a common failing of top management who are so smug about their feudal-mercantilist trader mode of operation that the innovatorentrepreneur role eludes them. In fact management in medium and small-scale sectors, we found, often believes that it is progressive but in fact every action of it retards progress and sustains status quo that in turn degenerates into inertia. But let us not be in any haste to paint everyone with the same wide brush. (39) 


\author{
(online) $=$ ISSN $2285-3642$ \\ ISSN-L = $2285-3642$ \\ Journal of Economic Development, Environment and People \\ Volume 3, Issue 3, 2014 \\ URL: $\underline{\text { http://jedep.spiruharet.ro }}$ \\ e-mail: office jedep@spiruharet.ro
}

Just examining techniques like cross-functional teams and developing creativity in employees through workshops or training, as many organizations have been prone to do is only a superficial attempt at encouraging innovation. (40) Many who talk about implementing ISO certification in academic institutions miss the point that rigid processes tend to stymie creativity. The certification assumes (erroneously) that if the process is perfect the product will also be perfect. The Indian civil service throws a spanner in the wheels of that argument and as we have elsewhere argued, one can perhaps obtain an ISO 9000 type of certification for manufacturing concrete life jackets! Moreover, such attempts do not adequately address underlying organization and behaviour patterns necessary for sustained product innovation. (48) These underlying patterns are termed organizational capacities and include socially shared orientations, as well as the skills and know-how that enable people to work in an innovative way. Much like the behaviour that enables people to live in a more healthy fashion, these organizational capacities may be more difficult to adopt than they are to identify, especially since it involves changes in current practices and ideas as both Senge (49) and Argyris (5) had earlier argued. (54)

Learning theory itself as far as innovation and creativity are concerned needs, in our opinion, to be seriously re-visited. In the recent years, research done by learning organization theorists and proponents of the knowledge-based firm has thrown considerable light on the approach necessary to institutionalise innovation. (43) Learning theorists, most notable among them being Peter Senge have looked at the organization as a whole - using a systems approach to analyse the relationships between components of the system in order to understand how they affect an organization's capacity for innovation and learning. (24)

\title{
2.2. The Metastrategic Cycle
}

Thus, one could argue that the starting point of our understanding could be to critically examine the configurations of the organization. Limerick and Cunnington have attempted to represent processes such as that we allude to in their model of a "Metastrategic Cycle". The Metastrategic cycle is a concept that links together vision, identity, configuration and organizational action. This cycle is depicted in the Figure below and has been extended from their 1993 work. (24) We believe this is relevant for the Indian environment even a decade later.

The Metastrategic cycle essentially has four basic elements or stages within it: Founding vision, Shared mindset, Configuration design, and Systems of action to understand this line of argument we need to make a journey through time and thought, which we attempt below (fig.1).

\section{The Founding Vision:}

Edgar Schein (47) had commented at length on the impact of the founder on the culture of the organization and which is only too well known for us to repeat here. This impact has largely to do with the founder's vision for the organization as a whole. Even a hundred years later the lofty vision, concern for mankind and sound ethical principles of Jamshedji Tata and Ardisher Godrej still echo in the corridors of their business empires. Schein argued that to choose a direction, a leader must first have developed a mental image of a possible and desirable future state of the organization. (47) This image, which we call a vision, may be as vague as a dream or as precise as a goal or mission statement. The critical point is that a vision articulates a view of a realistic, credible, attractive future for the organization; a condition that is better in some important ways than that which now exists 


\author{
(online) $=$ ISSN $2285-3642$ \\ ISSN-L = 2285 - 3642 \\ Journal of Economic Development, Environment and People \\ Volume 3, Issue 3, 2014 \\ URL: http://jedep.spiruharet.ro \\ e-mail: office jedep@spiruharet.ro
}

This idea of the founder's vision was ultimately related to both the means or values and the ends or purpose of the organization. In other words, the managers in such an organisation knew what the desired identity must be like in terms of the values and the purposes it must represent rather than merely the products it must create and markets it must secure. (52) Indeed they often explored many different product-market-technology combinations before selecting one that had sufficient promise to justify the building of an organization, and during this period their vision remained unaltered. Locating the Tata Iron and Steel Company in Jamshedpur way back in 1904 instead of at Nagpur where it was first thought of, is a case in point. The vision of the founding fathers of TISCO remained the same in spite of the relocation.

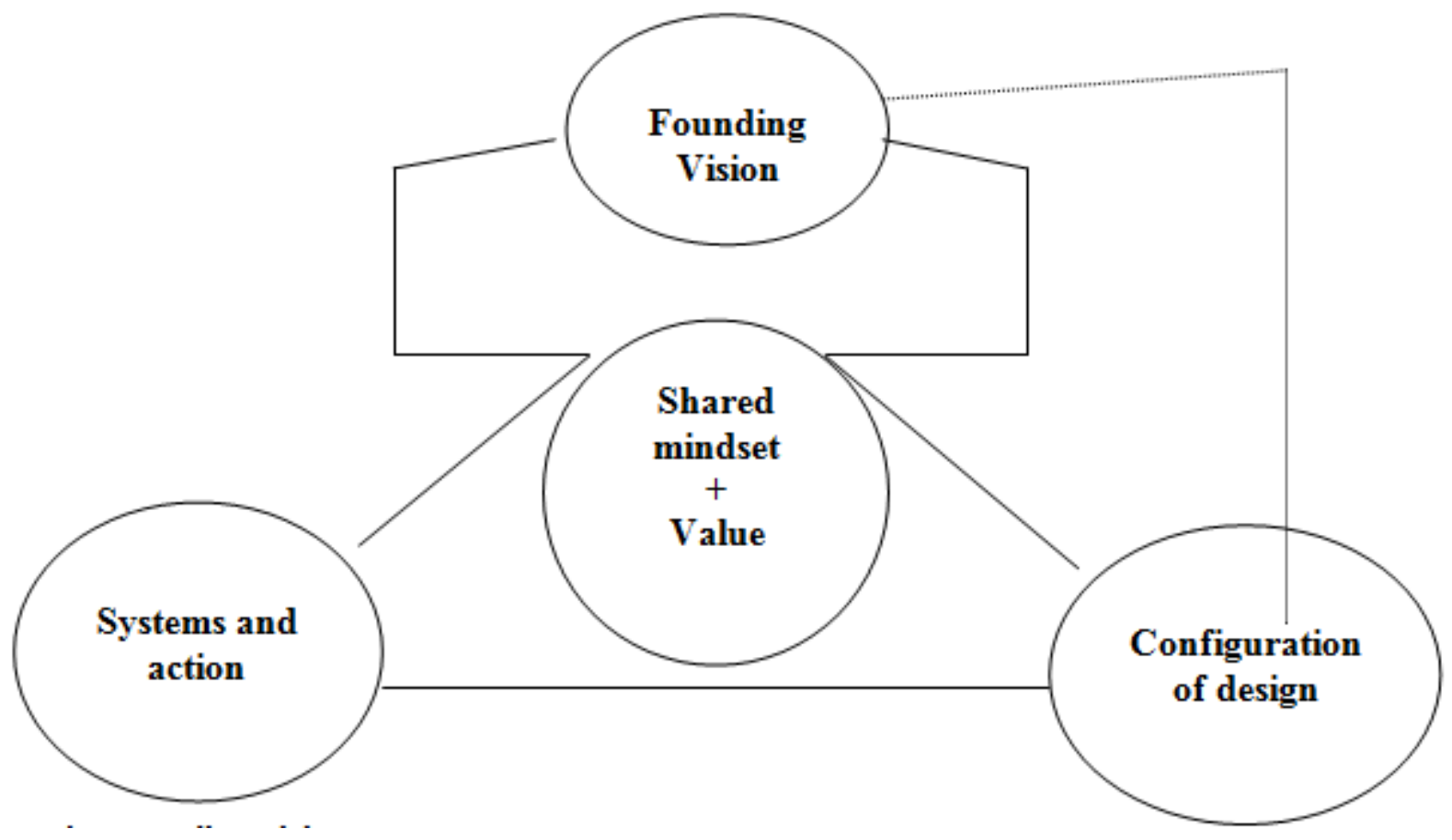

Fig. 1: The Metastrategic cycle.

\title{
The Shared Mindset and Value
}

The vision of the founder becomes established as a shared overall image, in the minds of those at the strategic apex of the organization, of the identity of the organization. This identity image consists of a number of elements, including:

- Its overarching values (11); and

- A continuing vision of the potential of the organization as it moves through the environment and through time. (13) 


\author{
(online) = ISSN $2285-3642$ \\ ISSN-L = 2285-3642 \\ Journal of Economic Development, Environment and People \\ Volume 3, Issue 3, 2014 \\ URL: $\underline{\text { http://jedep.spiruharet.ro }}$ \\ e-mail: office jedep@spiruharet.ro
}

Identity has no reality outside the meanings attributed to the organization and shared by its members as Sartre, (45) Aron ((6) and Popper (36) have severally pointed out. Linguistic scholars like Adorno (3) and Chomsky (10) have postulated that identity is, in effect, a socially constructed reality. It is a holistic, but somewhat inarticulate image, which often defies logic, represented subtly in the symbols, language, myth, labels, allegories and metaphors of the organization. But, for all its vagueness, it gives legitimacy and continuity to action. Effective strategic managers do attempt to make this image more concrete and accessible, often by writing it down in the credo, philosophy or mission statement of the organization that will spell out the purpose of its existence. (52)

\title{
The Configuration and Design
}

The shared mindset of the organization members, then, is a holistic image, often vague and implicit, of the continuing nature of the organization as it moves through social space and time. (53) Those at the strategic apex of the organization who hold this image must translate it into something more practical, into an integrated, operational model - a design that brings together a desired strategy, structure and culture of the organization into a coherent whole. (14) Like shard mindset, the configuration design of the organization may exist at different levels of explicitness and conscious articulation in different organizations. The clearer the overall configuration design, the more it allows role clarity to the organization members. However, the autonomy allowed to the individuals in the organizations depends upon the design of the organization structure. Rigid role descriptions and very high degree of formalization actually limit or in certain cases, kill autonomy. High degree of autonomy enables members to experiment constantly with the operational objectives, with structures and control processes, with strategic and operational values, and with the rituals, symbols and day-to-day routines without compromising on values. (16)

\section{The Systems and Action}

The configuration design of an organization provides a template for the development of the ongoing systems of action, which together form the organization. The entire grand design, which links together configuration and shared mindset, can become actuality only when various practical systems are developed to meet the needs of different product-market segments specified in the design. (17) People come together to create these systems of action. They negotiate them, and give them substance. Any single individual may move between many such systems, particularly in network organizations. While people create these systems of action on their own or as guided by the people at the apex, according to the shared mindset and the values, they may eventually swim with the established systems as the time passes. In this process, they may lose sight of original values or / and shared mindset. They become part of the comfortable routines, and over time these routines may be slowly modified and changed for more ease or betterment or to accommodate some highly visible business situations or the interests of the internal groups without damaging the comfort zones extensively. (16) Imperceptibly, these modified systems of action become meaningless rituals and may lead to a slower change in the very original shared mindset of the organization that has been shared by those within it. The cycle becomes closed: it moves from shared mindset to configuration to systems of action to the new-shared mindset. So the process of movement from vision to 


\author{
(online) $=$ ISSN $2285-3642$ \\ ISSN-L = $2285-3642$ \\ Journal of Economic Development, Environment and People \\ Volume 3, Issue 3, 2014 \\ URL: $\underline{\text { http://jedep.spiruharet.ro }}$ \\ e-mail: office jedep@spiruharet.ro
}

shared mindset to configuration to systems of action is ideal. In periods of stability, the actuality of the ongoing systems of action feeds back to influence the shared mindset of the organization held by its members, often including those at the strategic apex. However, the conditions controlling the business environment may be changing without creating ripples so that people may fail to take notice. What the organization does develops a momentum of its own, and becomes what the organization is. All within it become prisoners of its own implacable systems of action, imperceptible cogs in the wheel.(15)

Gould (1989) for example saw change as consisting of long periods of stable structure (equilibrium), punctuated by short periods of intense change and reconfiguration when a radical idea and innovation happen. (17) The deep structure of things tends to persist until apparently events like a new technology act to trigger a complete restructuring of the system. This, Gould argued, is essentially what chaos theory was attempting to capture i.e. emergence of order through fluctuation and chaos. Nonaka (1988) on the other hand expanded on the dynamics of this process. He argued that in a system condition, an element fluctuates. (30) It acts on the neighbouring elements one after another or competes with them, and the fluctuation begins to be amplified. When a macroscopic pattern begins to emerge from such a dynamic cooperative phenomenon, a feedback to each element takes place, reinforcing the dynamic co-operation. Thus a definite order is fixed spontaneously and a definite function is performed forming a stable order. When the order becomes fixed, the organic system again carries on a similar process irreversibly. As the order of a system becomes fixed, it is possible to discern a level of deep structure, a macroscopic pattern. But, if the processes of the organization were to be examined in detail, microscopically, it would be possible to discern even then a constant state of fluctuation and change which will eventually lead to a new pattern, which has within it constant fluctuation and change. (19)

The implications for organizations moving towards the rainbow of excellence under the above conditions are profound. The model argues for processes that allow elements to engage in collaborative self-organization out of chaos. The elements must be free to import energy, to fluctuate. At a microscopic level Chaos widens the spectrum of options and forces the organization to seek new points of view. (32)

For an organization to renew itself, according to us, it must keep itself in a non-equilibrium state at all times by maintaining a healthy level of stress. Pestonjee, (34) Pearce, (32) Nonaka (30) and Pankow (31) writing separately have reinforced this view. Yet at the same time elements within the organization must be able to recognize and manage levels of deep structure, and transcend and change these into new structures, which are more consonant with chaotic changes in the environment. This, in effect, is what Shell found among long-surviving organizations: de Geus (1988) on the one hand reported that they had one thing in common i.e., a tolerance for experimentation and differences among their elements. (13) They had highly autonomous units, which were permitted to move into new businesses and new industries. They allowed their own processes to be chaotic enough to match the chaotic nature of the environment. (14)

In sum, continuous learning and experimentation allows reconfiguration.(26) Those organizations that learn and adapt fastest are those that empower their elements to experiment. But they also have to act and think at a system-design level: they have to think about their co-operative identity, and move past it to a new identity and new configuration during periods of punctuation. (22) 


\author{
(online) = ISSN $2285-3642$ \\ ISSN-L = 2285-3642 \\ Journal of Economic Development, Environment and People \\ Volume 3, Issue 3, 2014 \\ URL: $\underline{\text { http://jedep.spiruharet.ro }}$ \\ e-mail: office jedep@spiruharet.ro
}

Powell argued that it is not sufficient to characterize these systems as open, adaptive, non- equilibrium, or learning systems; they are all that and more; they are self-transcendent, which means that they are capable of representing themselves and therefore also of transforming themselves (37). They have to be able continuously to challenge and transform their own concepts of identity. This can be an extremely subtle process. As Pankow has so aptly put it: For Pankow self transcendence means the capability to change one's own point of view, and therefore the capability to view a situation in a new light, (31) or, one might say, the ability to jump over one's shadow and this implies two things viz.

1. To be truly self-transcendent, the organization must be able to overcome what Argyris call its own "defensive routines" which enable managers and others to stay within the relative comfort zone of the current deep structure, whatever is happening in the environment? (5) It may well take the skills learned in a learning community, combined with the feedback from such a community, to overcome defensive routines, and to be able to redefine identity.

2. The organization must involve every member of the organization in the process, which moves from incremental to transformational change. Bass, for example, observes: But when the firm is faced with a turbulent marketplace; when its products are born, live and die within the span of a few years; and/or when its current technology can become obsolete before it is fully depreciated; then transformational leadership needs to be fostered at all levels in the firm.((8)

During periods of apparent stability, too, widespread involvement is also required in both continuous improvement processes and in experimenting with new ideas. From these could a new configuration not emerge? This is the million-dollar question that stares corporate leaders in the face as India prepares to enter the WTO regime in 2005. What we also need is a metrastrategic cycle in every sphere of business activity.

In sum, the innovative organization needs to be able to engage in changing and developing the entire metastrategic cycle, from change in shared mindset to constant change, experimentation and improvement in systems of action. (25) It must thrive in conditions of both stability and discontinuity. It must recognize that these two states are essentially part of the same process. The processes required for continuous improvement are also those that enable transformation and self-redefinition. And this is the much-needed lesson that our corporate leaders and management gurus must learn before it is too late (26).

Learning, to Revans implies both self-development and organizational development. (41) It proceeds particularly by questioning taken for granted assumptions. Innovation contributes to continuous improvement and transformational change because it involves collaborative questioning by organizational members of their own actions. Its immediate focus of attention might be systems of action, meta-strategic design and/or shared mindset - but, even when focusing on the more apparently superficial level of systems of action it remains alert to identity assumptions.

The essence of an innovative organization lies in a widely distributed capacity to question and redefine both individual and organizational identity. (24) This unique autonomy of individuals is the fundamental hallmark of an innovative enterprise. (25) Underlying this distributed questioning capacity in an innovative organization is a set of fundamental shared beliefs and values: 


\author{
(online) = ISSN $2285-3642$ \\ ISSN-L = $2285-3642$ \\ Journal of Economic Development, Environment and People \\ Volume 3, Issue 3, 2014 \\ URL: $\underline{\text { http://jedep.spiruharet.ro }}$ \\ e-mail: office jedep@spiruharet.ro
}

1. Current knowledge and skill are born of lived experiences occurring in a previous time and space and, in that sense, are environmentally relative.

2. Past experience can generate misconceptions, not only because our perceptual capacity is limited, but also because the past is different from the present and the future.

3. Learning can be defined as our ability to adapt and change with such readiness that we are seen to change.

4. People learn with and from, one another when they acknowledge their common ignorance and vulnerability.

5. Learning is a social process involving collaborative reflection on action.

The innovative organization contributes to continuous improvement and transformational change through a range of interdependent systems of action focused on individual and organizational development. Such an organization has the following characteristics that are further borne out by the works of Pedler (33) and Fletcher: (15)

- A bias for reflection-in-action

- Formation of learning alliances.

- Development of external networks.

- Multiple reward systems.

- Creation of meaningful information.

- Individual empowerment.

- Leadership and vision.

- A Bias for Reflection-in-Action

To this list we add four more based on our research. (47) (a) Adequate protection should be accorded to whistle-blowers if their bona fide intent is not proven. (b) Harsh legal action against corporate offenders such as those who indulge in insider trading and hacking into other businesses databases. (c) An end to political patronage of industry and business that usually operates on a quid pro quo basis. (d) Marginalizing the lumped mediocrity to prevent fixers and manipulators from hijacking the corporate agenda for personal gain albeit with the help of people in powerful places.

We argue along the lines of Peddler, (33) Kanter (22), Hamel et al, (18) Bass,(8) Adler (2), Hurley (19), Senge (49), Revans (41) and the rest that a bias for action is one of the characteristics of excellent organizations, and this is often contrasted with reflection, or with analysis paralysis. But in an actionlearning organization, it is the capacity of action to generate information, which is critically important to the organization. We emphasize the information-generating capacity of action when suggesting only after a concrete action has been taken will a concrete response (move) come back. Similarly, learning must be inextricably related to action since Learning cannot exist apart from action. Learning is the process for enhancing our capacity for effective action. Action learning has a similar bias but adds the reverse: action enhances learning because it provides a basis for the critical dimension of reflection. At the heart of action learning is the process of reflection which is designed to develop questioning insight - the capacity to ask fresh questions in conditions of ignorance, risk and confusion, when nobody knows what to do next. 


\author{
(online) = ISSN $2285-3642$ \\ ISSN-L = 2285-3642 \\ Journal of Economic Development, Environment and People \\ Volume 3, Issue 3, 2014 \\ URL: http://jedep.spiruharet.ro \\ e-mail: office jedep@spiruharet.ro
}

Not so recent research (53) points to the role of learning alliances in helping organizations to achieve continuous improvement and develop the capacity to cope with discontinuous change. The growing awareness of worldwide interdependence in the legal, economic, social, political and technological spheres have resulted in a burgeoning of alliances built on collaboration rather than aggressive self-reliance as Nonaka (30) and Bass (8) had separately suggested more than a decade ago. At the heart of this movement is the fundamental acknowledgement that no organization has all the skills and knowledge necessary to survive in the global market. Even the Honda Motor Company, founded on an ethos of total self-reliance, is confronted with the need to establish strategic alliances if it is to survive the current global shakeout in the industry. In India, there is an emerging trend of collaboration between elite engineering institutes and the premier I.T. companies to come together for software development (39)

Competition must be converted into collaboration for common good and this must be based on ethics and governance if the society itself has to excel. (12) The ability of individuals, groups, organizations, sectors, and nations to build strategic alliances is growing as a critical success factor for survival. Partnerships and joint ventures between corporate archrivals are already common, and simultaneous cooperation and competition between groups are growing. (1) Non-adversarial co-operative relationships between corporate management and suppliers, customers and Government are now essential. For this reason the view of Hamel et al. that "learning from partners is paramount" (18) for success is not only tenable but must be pursued with a passion.

In sum, alliances are networks that exist at an inter-organizational level. But in addition, an innovative and learning organization recognizes the social dimension of learning and the value of collaborative interdependence. These values are reflected in active support of external networks to support individuals and groups within the organization. Individuals are encouraged to form external networks and contribute to network development through the exchange of ideas, information and resources. There is recognition within the organization that enrichment of individuals through network activity is enrichment of the organization. (18) Networks are seen as fertile breeding grounds for the development of alliances that depend on the existence of prior relationships and mutual trust.

On the other hand, external network activity extends the scanning capacity of the organization. In innovative organization, leaders recognize that organizational culture is both help and a hindrance to strategic adaptation. Besides providing power for action, culture acts as a perceptual filter, a constraining frame for decision-making and a restraint on action options. Networking activity exposes the organization to alternative perceptions, decision processes and actions. The test of an innovative organization is whether management has the robustness to assimilate and act on information that is derived from premises that differ from those that are prevalent in the organization, particularly those held by the dominant coalition. Thus, external networks bring to the individuals and units within the organization the same kind of benefits reaped by broader organizational alliances.

The development of the innovative enterprise as an autonomous learning system creates a wider employment contract with employees than the basic agreement about wages for allocated work. Empowerment encourages levels of personal autonomy, which allow individuals to challenge current organizational concepts of identity. It is part of the development of collaborative individualism as any HR expert worth his salt knows. There is, within innovative organizations, the explicit recognition that 


\author{
(online) $=$ ISSN $2285-3642$ \\ ISSN-L = 2285 - 3642 \\ Journal of Economic Development, Environment and People \\ Volume 3, Issue 3, 2014 \\ URL: $\underline{\text { http://jedep.spiruharet.ro }}$ \\ e-mail: office jedep@spiruharet.ro
}

management's role is to provide continuous opportunities for employees' self-development. Revans had elaborated on this broadened perception of the contract of employment:

This wider bargain, even if not explicit, has deep implications for personal development and personal autonomy: outstanding persons should be encouraged to develop themselves to the limits of their capacities and ought not to be restricted entirely by ingenious mechanistic programs devised by quickwitted experts trained not to ask questions outside their own fields. Revan goes on to say that it is the responsibility of the expert to devise systems to cope with whatever problems this generates for the organization. In the final analysis, the organization values innovation above conformity and reflects this priority in its reward systems.

Kanter described 3M's reward system for product champions who include the opportunity to set up and manage their own divisions. (22) Many of 3M's innovations would not have made it to market if the organization had not developed the flexibility to establish a different form of reward system for the innovator. The challenge confronting organizations is to develop the capacity to reward both those who engage in continuous improvement within the existing identity frame and those who challenge organizational identity. The need to have multiple, and conflicting, exemplars heighten this dilemma. Organizations too have to find ways to reward their "network champions" that are rich sources of information and alliances. Nonaka had maintained that leaders need to play the role of a "strategic sponsor" to protect, nurture and sponsor creators of information.(30)

Innovative organizations are information-rich. External and internal networks, learning alliances and managerial reflections enhance information flows. Internal networks, developed through cross-functional action learning programs, heighten awareness of organizational resources, facilitate exchange and sharing of resources and generate information about interdependencies. (24) The group begins to experiment with the trial-and-error method for both thought and action. Action then clarifies and generates meaning allowing them to approach excellence. (25)

The writings of Revans (40), Senge (48) and Jayashree (21) continuously reinforce the need for autonomy of the individual and their empowerment to take action. They suggest that empowerment of individual workers will offer management their own opportunities to learn. But one thing that Sadri has pointed out earlier and it still remains valid. To give a manager empowerment without accountability is to create tyrants. To give a manager accountability without empowerment is to create slaves. Neither condition is either tenable or acceptable in the modern day. Top notch executives like Prakash Lal Tandon in PNB, Varghese Kurien in GCMMF (Amul), H T Parikh in HDFC, Sarosh J. Ghandy in Tata Motors (then TELCO), Tehmuras Doongajee in Tata-SSL now in Tata Services and E J Kalvachia in Godrej and Boyce had demonstrated years ago. (45) They showed that there is an enormous difference between an organization that is able to institutionalise innovation and one that is only capable of isolated episodes of learning and innovation through special task forces. In the latter, cycles are atomic and unrelated. In the former, they are all carried out within the context of reflection on the vision and identity of the organization. The basic insights of the transformational theorists, who focus on the vision provided by organizational leadership, are relevant to the innovative organization - and they are compatible with the views of the learning organization theorists. The responsibility of leaders, argues Senge, is to ensure that a shared vision does 


\author{
(online) $=$ ISSN $2285-3642$ \\ ISSN-L = $2285-3642$ \\ Journal of Economic Development, Environment and People \\ Volume 3, Issue 3, 2014 \\ URL: $\underline{\text { http://jedep.spiruharet.ro }}$ \\ e-mail: office jedep@spiruharet.ro
}

exist. (49) That vision can come from anywhere in the organization and good leaders are those who can disseminate the wheat from the chaff. We could sum up thus: top leadership is then concerned with:

- Building shared vision;

- Empowering people and inspiring commitment;

- Enabling good decisions to be made through designing-learning processes.

To us this view sounds remarkably like the picture of the envisaging, inspiring, enabling charismatic leader propounded by the transformational theorists. There are at least two reasons as scholars like Baldev Raj Sharma (50), Dinyar M Pestonjee (34) and T V Rao (39) have argued that a shared (and therefore commonly accepted) vision is so important to the creation of the action learning organization. First, an organization is directed by a vision is more likely to create discontinuities for its competitors than experience its own action as discontinuous. Second, it translates the individual learning event into an organizational action. By jointly reflecting on the meaningfulness of any event for the organizational mission as a whole, the amplification of the event and its communication throughout the organization are accelerated and organizational renewal is more likely. What emerges is a learning system, an innovative organization.

Without for a moment giving up the aim to approximate organisational excellence, we maintain that the ideas and innovation theory discussed above forms the framework from which the practices and structure of an innovative firm must flow, corporate governance must enable and top management must realise. Understanding the theory is important because only then does it become possible to put the ideas into practice. Understanding how the system components interact with each other provides an insight into what must be changed in order to create a constant orientation towards learning and align all in the organization towards innovation. The works of Amar, Miles and Meriden support this prognosis.

Perhaps the most important aspect of vision that underlies the innovative and learning organization, thus, is a new worldwide understanding of organizational and social effectiveness, which underlies the new organization. (51) Senge (48) has identified this overarching vision in Japan by stating that a new overarching vision seems to be emerging in Japan to characterize and guide this continuing evolution. The vision centres on creating the knowledge-creating company, an organization whose ability continually to improve its processes and systems comes from continually enhancing its underlying knowledge base. (52) Thus, the knowledge-generating organization is that which is most likely to be able to survive both equilibrium and chaos. Perhaps the final word should be given to Revans who said that the most precious asset of any organization is the one most readily overlooked: its capacity to build on lived experience, to learn from its challenges and to turn in a better performance by inviting all and sundry to work out for themselves what that performance might be.

Rejecting the futile dependence on regulations and regulators to attain excellence and forgetting for moment that Company Secretaries and Professional Accountants (unfortunately) continue to be in charge in corporate governance practices, we argue that if organisational excellence is to be approximated then top management involvement is imperative. Furthermore, a multi-disciplinary team facilitated by an expert in strategic HR intervention must manage corporate governance to lead this process of organisational transition towards excellence. 


\author{
(online) = ISSN $2285-3642$ \\ ISSN-L = $2285-3642$ \\ Journal of Economic Development, Environment and People \\ Volume 3, Issue 3, 2014 \\ URL: $\underline{\text { http://jedep.spiruharet.ro }}$ \\ e-mail: office jedep@spiruharet.ro
}

\title{
3. Conclusion
}

To conclude we posit that as India Inc. became an indubitable part of the post 2005 WTO Regime, industries will be increasingly forced to thrive on the cutting edge of competition. Competition will be so severe that they will have to keep running only to remain on the same spot. At such a point in time what will make a positive difference is reliability, consistency and marketability. This means that not only would management have to promote ethics through its policy but also ensure that it is maintained through practice. Ethics provides the foundation for corporate reliability, consistency and marketability. It is therefore the de facto basis for competition. Governance provides the parameters within which policies and practices will be followed thereby providing the de jure basis for competition. In addition, when ethics and governance combine movement towards excellence is facilitated. This is not something that is a onetime affair. It has to be zealously followed i.e. passionately and single-mindedly if corporate excellence is to be approximated. That is where India Inc. should be headed towards and make all out efforts to improve its global image and standing especially under the dynamic leadership of our new Prime Minister.

\section{Acknowledgement}

Gratitude with the usual disclaimers is extended to Prof. Jayashree Sadri, Maj Gen Balwinder Singh, Col. Anil Kumar Sharma, Dr S N Tara and Dr Abha Mohan for their comments on an earlier draft of this paper.

\section{References}

[1] Abraham, Don. (1998) Total Creativity in Business \& Industry: Road Map to Building a More Innovative Organization. Journal of Product Innovation Management. 15 (3). May.

[2] Adler, Terry R. Zirger, B J. (1998) "Organizational learning: Implications of a virtual research and development organization." American Business Review. 16(2): June

[3] Adorno, Theodor, (1964) (1986): The Jargon of Authenticity, London, Routledge and Kegan Paul.

[4] Amar, A D. (1998) Controls and Creativity in Organization. Mid-Atlantic Journal of Business. 34(2): 97-99. June.

[5] Argyris, C., (1991) "Teaching Smart People How to Learn", Harvard Business Review, May-June.

[6] Aron, Raymond (1957): The Opium of the Intellectuals, London, Secker and Warburg

[7] Aron, Raymond (1965): Main Currents in Sociological Thoughts, Vol. 1 \& 11, Harmondsworth. Penguin

[8] Bass, R., (1990) "From Transactional to Transformational Leadership: Learning to Share the Vision", Organizational Dynamics, Vol. 18, Winter.

[9] Bell, Daniel (1988): The End of Ideology, Harvard University Press, Massachusetts

[10] Chomsky, Noam (1968): Language and Mind, New York, Harcourt, Brace and Ward.

[11] Coleman, Henry J Jr. (1997) "Organizing in the knowledge age: Anticipating the cellular form." Academy of Management Executive. 11(4): 7-20. Nov.

[12] Cummings, Anne. Oldham, Greg R. (1997) "Enhancing creativity: Managing work contexts for the high potential employee." California Management Review. 40(1) fall.

[13] de Geus, A.P., (1988) "Planning as Learning", Harvard Business Review, March-April

[14] Field, Lloyd M. Walker, Terry. (1998) “Engaging employees in today's Corporations." Canadian Manager. 23(2) 


\author{
(online) = ISSN $2285-3642$ \\ ISSN-L = $2285-3642$ \\ Journal of Economic Development, Environment and People \\ Volume 3, Issue 3, 2014 \\ URL: http://jedep.spiruharet.ro \\ e-mail: office jedep@spiruharet.ro
}

[15] Fletcher, Winston. (1998) “Don't fear the tantrum.” Management Today. March.

[16] Gerstner, Louis V (2002): Who Says Elephants Can't Dance? (available on Internet)

[17] Gould, S.J., (1989) "An Asteroid to Die for", Discover, October.

[18] Hamel, G., Doz, Y.L. and Prahalad, C.K., (1989) "Collaborate with Your Competitors and Win", Harvard Business Review, Vol. 67 No. 1,.

[19] Hurley, Robert F. Hult, G Tomas M. (1998) "Innovation, market orientation, and organizational learning: An integration and empirical examination." Journal of Marketing. 62(3): July.

[20] Jayashree S (2004) What Every MBA Should Known About HRM, Himalaya Pub. Co., Mumbai.

[21] Jayashree S (2014): Fundamental Issues in People Management, Bharti Publications, New Delhi

[22] Kanter R.M., When Giants Learn to Dance: Mastering the Challenges of Strategy, Management and Careers in the 1990s, (1989) Simon \& Schuster, London.

[23] Kennedy van Dusen (1965) Unions Employers and Government, Manaktalas, Bombay.

[24] Kiechel, W., (1990): "The Organization That Learns", Fortune, Vol. 6, 12 March

[25] Levinson, H. and Rosenthal, S., (1984): CEO: Corporate Leadership in Action, Basic Books, New York, NY,

[26] Limerick, D. and Cunnington, B., (1993) Managing the New Organization: A Blueprint for Networks and Strategic Alliances, Business and Professional Publications, Sydney,

[27] Merriden, Trevor. (1998) “How the West turned Japanese." Management Today. September.

[28] Miles, Raymond E. Snow, Charles C. Mathews, John A. Miles, Grant Coleman, and Henry J Jr. (1997) “Organizing in the knowledge age: Anticipating the Cellular Form." Academy of Management Executive. 11(4) Nov.

[29] Nemeth, Charlan Jeanne. (1997) Managing Innovation: When less is more. California Management Review. 40(1): Fall.

[30] Nonaka, I., (1988) "Creating Organizational Order out of Chaos: Self-renewal in Japanese Firms", California Management Review, Vol. 30 No. 3, Spring

[31] Pankow, W., (1976) "Openness as Self-transcendence", in Jantsch, E. and Waddington, C.H. (eds), Evolution and Consciousness: Human Systems in Transition, Addison-Wesley, Reading, MA,

[32] Pearce, J.A., (1982) "The Company Mission as a Strategic Tool", Sloan Management Review, Vol. 23 No. 3.

[33] Peddler, M., (1991) Action Learning in Practice, 2nd ed., Gower, Aldershot,

[34] Pestonjee D M (1992): Stress and Coping: the Indian experience, New Delhi, Sage.

[35] Peters, T.J. and Waterman, R.H., (1982) In Search of Excellence: Lessons from America's Best Run Companies, Harper and Row, New York, NY.

[36] Popper, Karl Raimund (1961): The Property of Historicism, London, Routledge and Kegan Paul.

[37] Powell, Walter W. (1998) "Learning from collaboration: Knowledge and networks in the biotechnology and pharmaceutical industries." California Management Review. 40(3): Spring.

[38] Quinn, Brian James. (1985) “Managing Innovation: Controlled Chaos”, Harvard Business Review, May-June

[39] Rao T V (1990): The HRD Missionary, New Delhi, Oxford Univ. Press and IBH.

[40] Revans, R.W., (1968) "The Management Apprentice", Management International Review, Vol. 6. 


\author{
(online) $=$ ISSN $2285-3642$ \\ ISSN-L = 2285 - 3642 \\ Journal of Economic Development, Environment and People \\ Volume 3, Issue 3, 2014 \\ URL: http://jedep.spiruharet.ro \\ e-mail: office jedep@spiruharet.ro
}

[41] Revans, R.W., (1981) "Management, Productivity and Risk: The Way Ahead", Omega, Vol. 9 No. 2.

[42] Sadri S and Jayashree S (1998): When the Mediocrity is Empowered Woe to Thee Oh HR Professional, Management and Labour Studies, Winter.

[43] Sadri S and Ajgaonkar M (2003): Developing Capabilities for Learning and Innovation in Organisations, Prestige Journal of Management and Research, October.

[44] Sadri S Jayashree S and Ajgaonkar M (2002) Geometry of HR Himalaya Publishing Co., Mumbai.

[45] Sadri S Jayashree S and Sharma A K (2014) Organisational Excellence through Ethics and Corporate Bharti Publications New Delhi

[46] Sartre, Jean Paul (1991): Being and Nothingness, London, Routledge and Kegan Paul.

[47] Schein, E.H., (1983) "The Role of the Founder in Creating Organizational Culture", Organizational Dynamics, Vol. 12 No. 1.

[48] Senge P.M., (1990) The Fifth Discipline: The Art \& Practice of the Learning Organization, Bantam Doubleday Dell. New York.

[49] Senge, P.M., (1990) "The Leaders' New Work: Building Learning Organizations", Sloan Management Review, Vol. 32 No. 1.

[50] Sharma, Baldev R (1987): Not By Bread Alone: A Study of Organisational Climate and Employer-Employee Relations, New Delhi, Shri Ram Centre For Industrial Relations and Human Resources.

[51] Sheridan, John H. (1998) Nurturing Successful Innovation. Industry Week. 247 (10): 16. May 18.

[52] Somogyi, Stephan. (1998) "Harnessing Creativity." Upside. 10(8): August

[53] Stein, Robert G. Pinchot, Gifford.(1998) “Are you innovative?” Association Management. 50(2): Feb.

[54] Tennenbaum, Toby J. (1998): Shifting Paradigms: From Newton to Chaos. Organizational Dynamics. 26(4): Spring. 